\title{
Preliminary findings on vaginal epithelial cells and body temperature changes during oestrous cycle in Bororo zebu cow
}

\author{
J. P. Kilekoung MINGOAS ${ }^{{ }^{*}}$ and L. Lalaud NGAYAM ${ }^{2}$ \\ ${ }^{1}$ School of Medicine and Veterinary Sciences, University of Ngaoundere, P.O. Box 454 Ngaoundere, \\ Cameroon. \\ ${ }^{2}$ Department of Biological Sciences, Faculty of Science, University of Ngaoundere, Cameroon. \\ ${ }^{*}$ Corresponding author, Phone: (237) 758560 14, E-mail: jmingoas@yahoo.fr
}

\begin{abstract}
A study was carried out on 18 Bororo zebu cows in Yagoua within the Sudano-sahelian zone of Cameroon, in order to assess vaginal cytology and body temperature variations during oestrous cycle. Swabbing was done daily in the vagina, and vaginal smears were stained according to Romanowski method. Rectal temperature of each cow was monitored once daily at 06:00. Data were collected for 28 consecutive days. Before oestrous period, intermediate and parabasal cells rates were similar $(Z=0.47)$, but higher than superficial $(Z=2.19)$ and keratinized $(Z=2.61)$ cells rates. In general, percentage of basal and parabasal cells evolved as a pyramid with a minimum on days 7 and 2 respectively before oestrous. During oestrous period, superficial cells percentage was significantly higher than that of intermediate $(Z=3.39)$, parabasal $(Z=4.42)$, basal $(Z=5.70)$ and keratinized $(Z=5.58)$ cells. In post-oestrous, parabasal cells percentage was higher than superficial $(Z=2.13)$, intermediate $(Z=3.01)$ and basal $(Z=2.88)$ cells rates, but similar to keratinized cells rate $(Z=0.40)$. Body temperature during oestrous was significantly higher $(\mathrm{P}<0.05)$ than in pro-oestrous and post-oestrous.
\end{abstract}

(C) 2009 International Formulae Group. All rights reserved.

Key words: heat detection, vaginal cytology, Bororo zebu cattle.

\section{INTRODUCTION}

Low oestrous detection efficiency is known as one of the main causes of poor fertility rate in zebu cow (Seegers et al., 2005). This lead to prolonged calving to calving and calving to conception intervals, and also to low herd technical and economic performance, even in developed countries such as Netherlands and USA (Saumande, 2000).

This situation results from poor reproductive practices commonly observed in livestock production systems in the tropics as well as in the periurban zone of Ngaoundere, in Cameroon (Mingoas et al., 2006).

Visual methods for oestrous detection are well documented, but their use and their efficiency are controversial (Hicham, 2001).
In addition, silent heat in zebu cows is a supplementary difficulty to visual oestrous detection, and other techniques such as electronic mounting detection and hormones profile monitoring appear to be very expensive for low income livestock production systems.

Vaginal cytology changes during oestrous cycle have been studied in sheep (Hounzangbe-Adote, 1994), goats (Ola et al., 2006), swine (Valerie et al., 2003) and in boars (Mayor et al., 2005), but little is known about this issue in cows, especially in zebu cows.

The objective of this study was to contribute to heat detection efficiency by 
evaluating vaginal cytology combined to body temperature changes during oestrous cycle.

\section{MATERIALS AND METHODS}

The study was carried out on Bororo zebu cows previously described (Pagot, 1985; Douffissa, 1993), reared in an extensive livestock system in Yagoua, within the sudano-sahelian zone of Cameroon (10-11 ${ }^{\circ}$ $\mathrm{LN}$ and $\left.14-15^{\circ} \mathrm{LE}\right)$, where there is a prolonged dry season (7-8 months) and a short rainy season. The average temperature is $28^{\circ} \mathrm{C}$ with variations of $7.7^{\circ} \mathrm{C}$ and maximum temperature of 35 to $45{ }^{\circ} \mathrm{C}$ from March to May.

Data were obtained on 18 zebu cows of 3 to 5 years. Oestrous was detected twice daily (05:30-06:30 and 18:00-18:30), for 28 days by visual observations. The occurrence and the duration of behavioural signs of oestrous were recorded for each cow.

Swabbing was done daily in the vagina, and vaginal smears were stained according to Romanowski method (Argawal., 2005). Rectal temperature of each cow was monitored once daily at 06: 00 .

Identification of vaginal epithelial cells was performed by microscopic observation (Gx100), based on their morphological and stained characteristics (Hounzangbe-Adote, 1994; Valerie et al., 2003).

The percentage of vaginal cells was calculated as the number of each type of cell divided by the total number of cells seen within 2 microscopic fields.

Vaginal cells percentages and body temperature were respectively compared by using Z formula (Schwartz, 1993) and Student t-test at significance level of $5 \%$.

\section{RESULTS}

During the study a total of 5 types of vaginal cells were identified. Their percentage varied according to oestrous cycle phase (Table 1).

In pro-oestrous, intermediary and parabasal cells proportions were not different $(Z=0.47)$, but significantly higher than superficial $(Z=2.19)$ and keratinized $(Z=$ 2.61) cells percentages.

Oestrous phase was characterized by a significant higher rate of superficial cells as compared to intermediaries $(Z=3.39)$, parabasal $(Z=4.42)$, basal $(Z=5.70)$ and keratinized $(Z=5.58)$ cells. This rate was also significantly higher $(Z=4.86)$ in oestrous than that observed in pro-oestrous.

Post-oestrous was typically characterized by a relatively great proportion of parabasal and keratinized cells.

Vaginal cells monitoring during the oestrous cycle showed that there was a high level of parabasal and intermediary cells on days 4 and 6 before oestrous respectively, and on days 6 and 11 post-oestrous for parabasal and keratinized cells respectively, which appeared again from days 2 and 6 after oestrus period with basal and intermediary cells (Figure 1).

During oestrous phase, superficial cells reached their higher rate $(47 \%)$ on day 1 of the cycle, while other vaginal cells were at their lower level between oestrous day and day 1 post-oestrous.

Table 1: Vaginal cells changes (\%) during oestrous cycle in Bororo zebu cows.

\begin{tabular}{lccc}
\hline \multirow{2}{*}{ Vaginal cells } & \multicolumn{3}{c}{ Estrus cycle phases } \\
\cline { 2 - 4 } & $\begin{array}{c}\text { Pro-estrus } \\
(\mathbf{n}=\mathbf{1 2})\end{array}$ & $\begin{array}{c}\text { Estrus } \\
\mathbf{( n = 1 2 )}\end{array}$ & $\begin{array}{c}\text { Post-estrus } \\
\mathbf{( n = 1 2 )}\end{array}$ \\
\hline Basal & $19.0^{\mathrm{b} \alpha \beta}$ & $10.0^{\mathrm{a} \alpha}$ & $18.4^{\mathrm{b} \alpha}$ \\
Parabasal & $22.4^{\mathrm{ab} \beta}$ & $15.8^{\mathrm{a} \alpha \beta}$ & $23.4^{\mathrm{b} \beta}$ \\
Intermediaries & $23.3^{\mathrm{b} \beta}$ & $21.2^{\mathrm{ab} \beta}$ & $18.2^{\mathrm{a} \alpha}$ \\
Superficial & $18.0^{\mathrm{a} \alpha}$ & $43.0^{\mathrm{b} \gamma}$ & $18.8^{\mathrm{ab} \alpha}$ \\
Keratinized & $17.3^{\mathrm{c} \alpha}$ & $10.0^{\mathrm{a} \alpha}$ & $21.2^{\mathrm{b} \alpha \beta}$ \\
\hline
\end{tabular}

$\mathrm{a}, \mathrm{b}, \mathrm{c}$ : values in the same row with the same superscript are not significantly different at $5 \%$ level.

$\alpha, \beta, \gamma$ : values in the same column with the same superscript are not significantly different at $5 \%$ level.

(n) : number of measurements. 


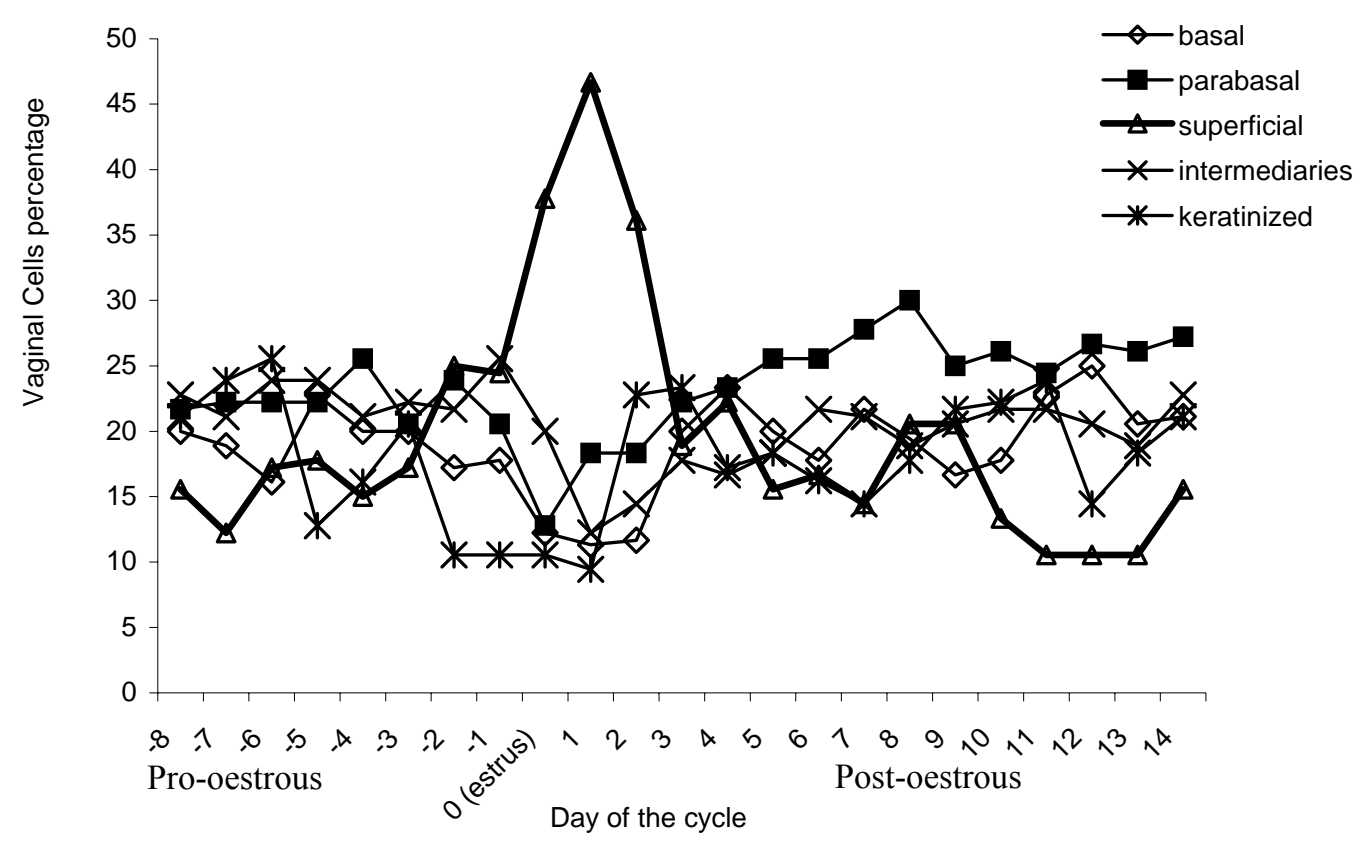

Figure 1: Vaginal cells evolution during estrus cycle in Bororo zebu cows.

Table 2: Body temperature changes during oestrous cycle in Bororo zebu cows.

\begin{tabular}{lc}
\hline Estrus cycle phases & Mean body temperature $\left({ }^{\circ} \mathbf{C}\right)$ \\
\hline Pro-estrus $(\mathrm{n}=12)$ & $37.58 \pm 0.78^{\mathrm{a}}$ \\
Estrus $(\mathrm{n}=12)$ & $38.31 \pm 0.63^{\mathrm{b}}$ \\
Post-estrus $(\mathrm{n}=12)$ & $37.68 \pm 0.32^{\mathrm{a}}$ \\
\hline
\end{tabular}

$\mathrm{a}, \mathrm{b}$ : values with the same superscript are not significantly different at $5 \%$ level.

\pm standard deviation.

(n) : number of measurements.

Body temperature monitored during the estrus cycle appeared to be higher $(\mathrm{P}<0.05)$ in oestrous as compared to pro-oestrous and post-oestrous phases (Table 2).

A lower temperature was recorded on days 7 and 1 before oestrous (Figure 2), and a great drop was observed on day 1 postoestrous.

\section{DISCUSSION}

Vaginal epithelial cells proportions trend recorded during oestrous phases is similar to what was previously reported by Hounzangbe-Adote (1994) in sheeps, Rodgers et al. (1993) and Valerie et al. (2003) in sows,
Ola et al. (2006) in goats and by Mayor et al. (2005) in boars, although variations are observed in their rate, which could be due to genetic factors in relation with each specie and environmental conditions. In fact, Bororo zebu cows are reared in dry and harsh environment of sudano-sahelian zone, with lack of fresh forage during the long dry season.

Day by day vaginal cells changes monitoring during the oestrous cycle is also in accordance with what was observed in the mouse vagina by Harold (2005) and on brushtailed porcupine by Mayor et al. (2003) who concluded that this could be used as predictors of oestrous cyclicity. 


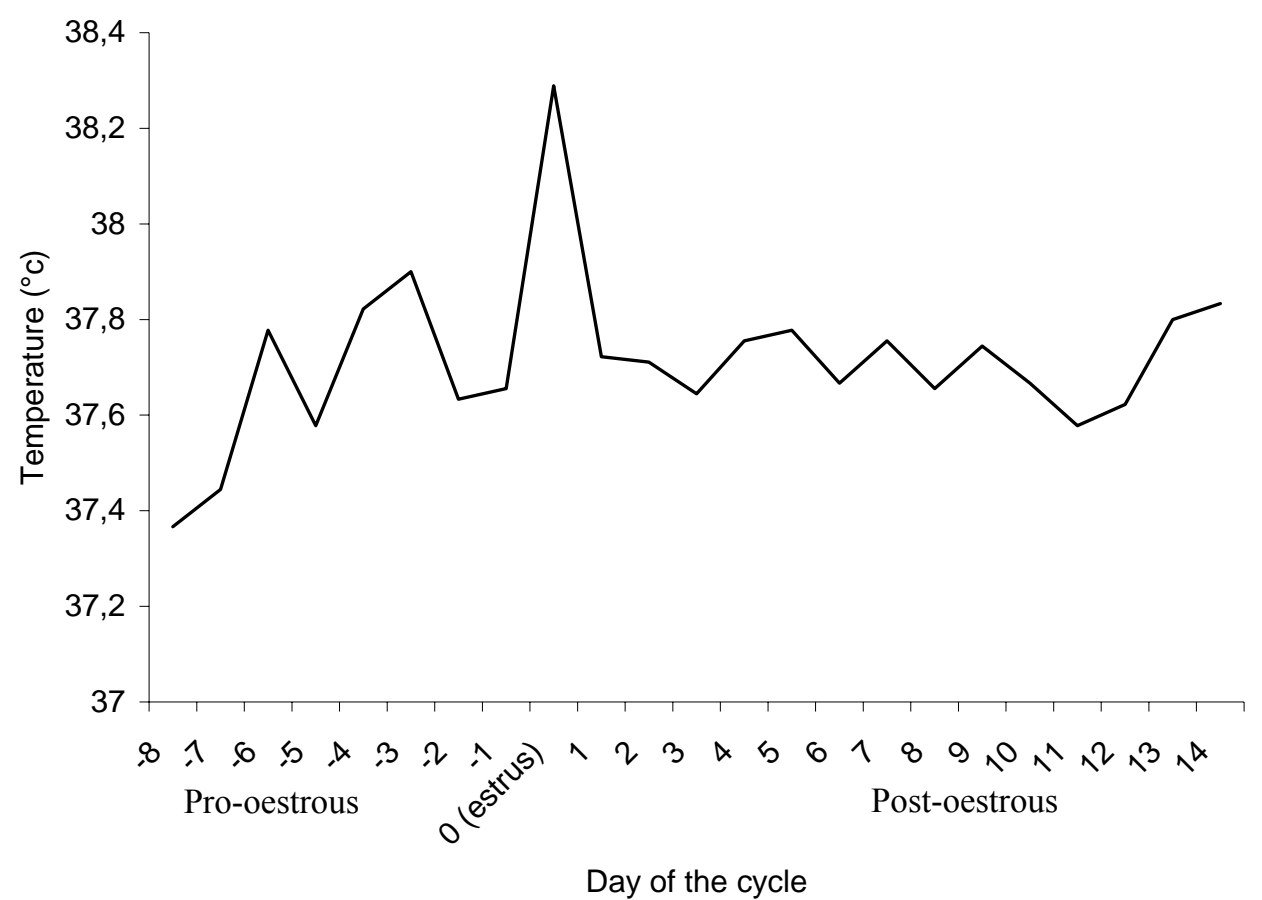

Figure 2: Body temperature evolution during oestrous cycle in Bororo zebu cows.

The rate of superficial cells we recorded $(47 \%)$ on oestrous day was lower than those obtained on mouse by Harold (2005), on sow by Rodgers et al.(1993) and Valerie et al.(2003) and on boar by Mayor et al.(2005), which ranged from 60 to $90 \%$ on oestrous day. These results were obtained from different species and different environmental conditions and this could have played a great role on differences with the findings on Bororo zebu cows.

Body temperature in oestrous period was higher as compared to pro-oestrous and post-oestrous phases. Wolfenson et al. (1995) and Guiseppe et al. (2003) registered 2 and $1^{\circ} \mathrm{C}$ higher respectively on cows. Body condition score and genetics factors among others could probably explained the differences (Guiseppe et al., 2003).

We recorded a lower temperature on days 7 and 1 before oestrous, and a great drop on day 1 post-oestrous. Wrenn et al. (1958) and Oshaki et al. (1984) observed a low body temperature 2 and 3 days before oestrous, which rapidly increased on oestrous day and dropped on the day following oestrous, and gradually increased in the luteal phase of the cycle.

The higher body temperature recorded during oestrous period could be due to the maximum size of the dominant follicle and to intense activities of cows in oestrous, as it was previously reported by Asdell (1955) quoted by Wrenn et al. (1958). However, body temperature could also be influenced by environment (Mundia and Yamamoto, 1997) and by the rhythm of cow activities (Refinetti, 1999).

\section{Conclusion}

Preliminary results on vaginal epithelial cells and body temperature changes during oestrous cycle showed that high rate of superficial cells and high body temperature could be considered as main oestrous period characteristics and could also be a useful tool for heat detection in Bororo zebu cow.

\section{REFERENCES}

Agarwal SP. 2005. Staining Methods in Cytology. Manuel for Cytology: India.

Douffissa A. 1993. L'élevage Bovin dans le Mbéré (Adamaoua camerounais). 
Collection Etude et Synthèse. ORSTOM: Bondy, France.

Giuseppe P, Giovanni C, Roberto R. 2003. Temperature of cow, variation during estrous cycle. BMC Physiology, 3: 7.

Harold HT. 2005. Epithelial cell proliferation in the mouse vagina during the estrous cycle, pregnancy and lactation: A radioautographic study. The Anatomical Record, 170(4): 457-469.

Hicham H. 2001. Gestion de la reproduction chez la vache: insémination artificielle et détection des chaleurs. Rapport. Institut Agronomique et Vétérinaire Hassan II Maroc, p.11.

Hounzangbe-Adote MS. 1994. Etude du Cycle Oestral chez la Brebis Djallonké. Small Ruminant Performance and Reproduction: Bénin; 111-116.

Mayor P, Lopez-Béjar M, Jori F, Fenech M, Lopez-Gatius F. 2003. Reproductive functional anatomy and oestrous cycle pattern of the female brush-tailed porcupine (Atherurus africanus, Gray 1842) from Gabon. Animal Reproduction Science, 77(3, 4): 247-259.

Mayor P, Galvez H, Guimaraes DA, LopezGatius F, Lopez-Bejar M. 2005. Serum estradiol-17 $\beta$, vaginal cytology and vulval appearance as predictors of estrus cyclicity in the female collared peccary (Tayassu tajacu) from the eastern Amazon region. Animal Reproduction Science, 97: 165-174.

Mingoas KJP, Gambo H, Ottou JFB, Ebangi AL, Domwa M. 2006. Structure des troupeaux et conduite de l'Elevage bovin périurbain de Ngaoundéré au Cameroun. Bulletin of Animal Health and Production in Africa, 54(1): 53-65.

Mundia CM, Yamamoto S. 1997. Day-night variation of thermoregulatory responses of heifers exposed to high environmental temperatures. Journal of Agricultural Science, 129: 199-204.

Ohsaki K. 1984. A study of the body temperature variations in Dairy Cattle in relation to their reproductive status -
Estrous cycle, Pregnancy and Parturition. Jpn. J. Vet. Res., 32: 112.

Ola SI, Sanni WA, Egbunike G. 2006. Exfoliative vaginal cytology during the oestrous cycle of West African dwarf goats. Reproduction Nutrition Development, 46: 87-95.

Pagot J. 1985. L'élevage en Pays Tropicaux. Edn G.-P. Maisonneuve-Larose: Paris.

Refinetti R. 1999. Relationship between the daily rhythms of locomotor activity and body temperature in eight mammalian species. Am. J. Physiol., 277: 1493-1500.

Rodgers JB, Sherwood LC, Fink BF, Sadove RC. 1993. Estrus detection by using vaginal cytologic examination in miniature swine. Laboratory Animal Science, 43(6): 597-602.

Saumande J. 2000. La détection électronique des chevauchements pour la détection des vaches en chaleur : possibilités et limites. Revue Médecine Vétérinaire, 151(11): 1011-1020.

Schwartz D. 1993. Méthodes Statistiques à l'Usage des Médecins Biologistes ( $4^{\mathrm{e}}$ édn). Médecine-Science: Paris.

Seegers H, Grimard B, Billon D. 2005. Effets économiques liés à la qualité de détection de l'oestrus en troupeau bovin laitier. Renc. Rech. Ruminants, 12.

Valerie R, Beimborn M, Heather L, Tarpley, Perry JB, Kenneth SL. 2003. The Canine Estrous Cycle: Staging Using Vaginal Cytological Examination. Veterinary Clinical Pathology Clerkship Program, The University of Athens, $6 \mathrm{p}$.

Wolfenson D, Thatcher WW , Badinga L, Savio JD, Meidan R, Lew BJ, Braw-Tal R, Berman A. 1995. Effect of heat stress on follicular development during the estrous cycle in lactating dairy cattle. Biology and Reproduction, 52(5): 11061113.

Wrenn TR, Bitmann J, Sykes JF, 1958. Body temperature variations in dairy cattle during the estrous cycle and pregnancy. Journal of Dairy Science, 41(8): 10711076. 